often be inadequate for subjects which are no longer well known to the newcomer, such as Regge behaviour. A more detailed discussion of some topical questions (in particular those involving perturbative QCD) would have been useful to bring the reader fully abreast of present applications. One should, however, mention a detailed presentation of the parton model in a field theoretic language which has recently provoked much interest.

Despite its being too short to meet all requirements, this little book should certainly provide the reader with ideas and with a better understanding of present approaches to high energy interactions.

Maurice Jacob is a senior scientist in the Theoretical Study Division of CERN and a corresponding member of the French Académie des Sciences.

\section{Hypoxia as a way of life}

\section{R. D. Harkness}

Living without Oxygen: Closed and Open Systems in Hypoxia Tolerance. By Peter W. Hochachka. Pp.181. (Harvard University Press: 1980 .) $\$ 17.50, £ 10.50$.

THE thing that strikes you immediately about this book is that the author is an enthusiast. And not simply an enthusiast, but one whose enthusiasm has led him to bring together a great diversity of material to make a coherent story. There is a point in everything he has written, and that, is an unusual achievement for a work that is primarily about biochemistry, a subject prone to accumulation of disconnected facts.

The book is concerned with the ways in which animals obtain energy when they have limited or no access to oxygen. For some this is part of their way of life (intestinal parasitic worms, deep-sea fishes); for others it is a temporary state (fishes wintering in stagnant water, lungfishes sealed in dried mud, bevalve molluscs with their shells shut, seals and other marine mammals when diving). The same sources can provide, for rapid movement, a short-lived burst of energy at a higher rate than could be achieved with the use of oxygen alone (vertebrate and cephaloped muscle). This latter mechanism by degradation of carbohydrate (glycogen) to lactic acid, will be familar to many who would, like myself, be ignorant of other things dealt with in this book. However, the production of lactic acid has snags - its acidity which can adversely affect other tissues. The effect is reduced in diving mammals by use of the acid in organs privileged to have what little oxygen is available, principally the brain and heart (and also, curiously, the adrenals). The problem can also be solved by the production of less awkward end-products, such as by creatures with particular adaptation. One, curiously, is alcohol, produced by goldfish under conditions where little oxygen is available. The fish make ethanol by using in reverse the same set of enzymes as we do to destroy it. how much they enjoy their grog we don't know, but it is nice to think of them quietly solacing themselves as they lie in winter in the mud at the bottom of a cold pond waiting for the spring; and maybe solace others too as they get rid of the alcohol into the surrounding water.

There is much more like this on the curious adaptations which have evolved to enable animals to operate in unusual environments made interesting by the fact that the author is not only a biochemist but also a zoologist. This is what really makes this book so fascinating - he puts the biochemistry into the whole picture of the physiology and life-style of the animals.

So this is a good book which should certainly be in any library that caters for degree students. Is there, then, nothing wrong or the lack of something that would make it better? The approach is primarily biochemical, and the reader needs to be familiar with both the general concepts and the facts of biochemistry. For example, no chemical formulae of compounds are given, only names; enzymes are shortened to abbreviations, explained it is true at the first mention, but not easy to find if you want to check; there is no glossary. Yet the book will interest many who are unfamiliar with biochemical terms, and a short general summary of the biochemical background would be of great value to the nonspecialist. To argue that the information is available elsewhere is to miss the point that it is not available when and where it is wanted. Written by Professor Hochachka, at the start of the book, it would not only be in the right place but also probably clearer and more pertinent than anything one could easily find elsewhere.

In one of my excursions into history I came across William Robertson, a most readable 18 th century man, who habitually started you off a few hundred, if not thousands, of years earlier. So it would be nice if this book could start in the same sort of way to make it more easily understandable, possibly not to historians, but to a range of people who would find it very interesting but at the moment rather a struggle. So, in summary, an alpha now, and every prospect for an alpha plus for the next edition.

R. D. Harkness is Professor of Physiology at University College London, whose main interest has been in connective tissue with a bias towards comparative physiology.

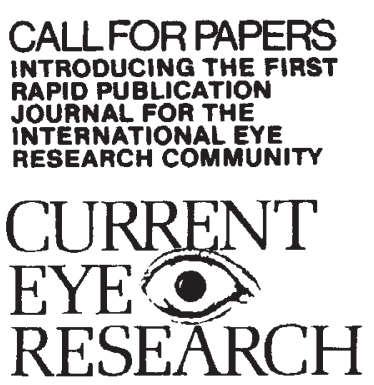

Monthly

Commencing January 1981

\section{Executive Editors}

C. A. Paterson and

N. A. Delamere

University of Colorado,

Health Sciences Center,

4200 E. Ninth Ave. Denver

Colorado 80262, USA.

\section{Editorial Board}

The following have provisionally accepted the invitation to join the editorial board

Netherlands

USA

R. P. Burns

USA

G. D. Cagle

U.D. Ca

O. A. Candia

USA

$H$. Cheng

England

R. L. Church

USA

C. Cintron

USA

S. Dikstein

Israel

Israe

Edeinauser

USA

K. E. Eakins

England

P. N. Farnsworth

USA

R. F. Fishe

England

K. Green

USA

S. I wata

Japan

P. L. Kaufman

USA

Y. Kikkawa

Japan

S. D. Klyce

USA

H. Maisel

USA

J. McAvoy

Australia

G. Maraini

Italy

S. A. Miller

USA

J. Obenberger

Czechoslovakia

E. S. Perkins

USA.

R.R. Pfister

USA

J. L. Rae

USA

M. Reim

Vest Germany

M. V. Riley

USA

T. O. Wood

USA

T. J. Zimmerman USA

The principal aim of Current Eye Research is to provide rapid publication of full papers, short communications and minireviews, each of high

quality.

To ensure rapid publication. accepted articles will be printed directly from camera-ready typescripts prepared by the authors.

Current Eye Research will consider articles encompassing all the areas of eye research. The subject areas include clinical research anatomy. physiolesearch, anatom

physiology, biophysics,
biochemistry, pharmacology, developmental biology developmental biology,
microbiology and immunology. Specially ruled typing sheets and detailed instructions to Authors' can be obtained from either the editors or the either the edishers.
publish

\section{IRL IRL Press Ltd}

Suite 815, Fisk Building

250 West 57 th Street

New York, NY 10019, USA

P.O. Box 1

Eynsham, Oxford OX8 1JJ. UK

Free sample issue available on request. 